\title{
Downregulation of Adenylylcyclase Types V and VI mRNA Levels in Pacing-induced Heart Failure in Dogs
}

\author{
Yoshihiro Ishikawa, ** Steve Sorota, * Kaname Kiuchi," Richard P. Shannon, Kazuo Komamura, Shuichi Katsushika, * \\ Dorothy E. Vatner, 'Stephen F. Vatner," and Charles J. Homcy" \\ Departments of ${ }^{*}$ Pharmacology and ${ }^{\ddagger}$ Medicine, College of Physicians and Surgeons of Columbia University, New York 10032; \\ 'Department of Medicine, Harvard Medical School, The New England Regional Primate Research Center, Southborough, Massachusetts \\ 01772; and "Medical Research Division, American Cyanamid Company-Lederle Laboratories, Pearl River, New York 10965
}

\begin{abstract}
We have shown that the heart expresses two distinct forms of adenylylcyclase mRNA, types $V$ and VI. In this study we have characterized the expression of these two mRNA species in heart failure generated by overdrive pacing at a rate of 240 beats $/ \mathrm{min}$. After $4 \mathrm{wk}$, left ventricular end-diastolic pressure and heart rate increased significantly with the appearance of signs of heart failure, i.e., edema, ascites, and exercise intolerance. Basal as well as forskolin-stimulated adenylylcyclase activities decreased significantly, which was accompanied by a reduction in the steady state mRNA levels of adenylylcyclase types V and VI. These data suggest that in this model of cardiomyopathy, the downregulation of adenylylcyclase catalytic activity results, at least in part, from a reduction in the steady state levels of types $\mathrm{V}$ and $\mathrm{VI}$ adenylylcyclase mRNA levels. (J. Clin. Invest. 1994. 93:2224-2229.) Key words: cardiac adenylylcyclase • mRNA • heart failure • cardiac pacing • downregulation
\end{abstract}

\section{Introduction}

For more than three decades, clinical investigators have recognized that impaired sympathetic stimulation contributes to the development of heart failure. CAMP generation through activation of adenylylcyclase via the $\beta$-adrenergic receptor represents a major mechanism for enhancing cardiac contractility (1). Defects in catecholamine release, $\beta$-adrenergic receptor content, receptor- $\mathrm{G}_{\mathbf{s}}$ coupling, and adenylylcyclase catalytic activity have been identified in tissues removed from failing human hearts $(2,3)$ and in the hearts of animals with experimentally induced heart failure (4-6). However, the significance and the relationship of these changes are difficult to judge because the process of heart failure can only be studied over a long time period in intact animals. Nevertheless, a recent report suggests that an abnormality in myocardial cyclic AMP production may be a fundamental defect present in patients with end-stage heart failure (2). In both pressure overload and overdrive pacing-induced models of heart failure, we have found that heart failure was characterized not only by an uncoupling of the $\beta$ -

Address correspondence to Charles J. Homcy, M.D., Medical Research Division, American Cyanamid Company, Lederle Laboratories, Pearl River, NY 10965.

Received for publication 8 September 1993 and in revised form 27 December 1993.

J. Clin. Invest.

(c) The American Society for Clinical Investigation, Inc.

0021-9738/94/05/2224/06 \$2.00

Volume 93, May 1994, 2224-2229 adrenergic receptor from $\mathrm{G}_{\mathrm{s}}$ in ventricular sarcolemma but also by a decrease in adenylylcyclase activity, whether it was stimulated by the $G$ protein or forskolin $(5,6)$. The pacing-induced model is particularly useful because ventricular dysfunction can be produced within several days of initiation of rapid ventricular pacing (6-8). This model has a human parallel: several case reports describe patients in whom heart failure and biventricular dilatation occurred in the setting of supraventricular tachycardia only to be reversed after the tachycardia had ceased (9-11). Similarly, in the canine pacing-induced heart failure model, contractile function gradually returns upon cessation of pacing.

The cloning, structure, and function of six isoforms of mammalian adenylylcyclase (types I-VI) have been reported (12-17). Each isoform has a particular tissue distribution, for example, type I exists only in the brain, type III in the olfactory bulbs, whereas type IV is widely expressed in a variety of tissues. These adenylylcyclase molecules together with a large family of proteins, including the multiple drug resistance (18) and cystic fibrosis gene products (19), share a common motif; a tandem repetition of a unit containing six transmembrane spans followed by a large hydrophilic intracellular domain.

We have recently identified the type $\mathrm{V}$ and $\mathrm{VI}$ isoforms of adenylylcyclase by cloning from a canine cardiac cDNA library $(16,17)$. Both types of mRNA are abundantly expressed in heart and brain; however, unlike type V, type VI is also expressed at low levels in a variety of other tissues. Types $\mathrm{V}$ and VI share $<40 \%$ homology with other isoforms of adenylylcyclase although they are $65 \%$ homologous with each other. When expressed in CMT cells, both types can be stimulated by $\mathrm{NaF}, \mathrm{GTP} \gamma \mathrm{S}$, and forskolin but not by $\mathrm{Ca}^{2+}$-calmodulin, whereas both types are inhibited by adenosine and its analogs. Close resemblance in tissue distribution, biochemical features, and sequence suggests that type $\mathrm{V}$ and type VI form a subclass within the mammalian adenylylcyclase family, i.e., a cardiac adenylylcyclase subfamily (17).

In the present study we used type V and type VI cDNA clones as probes for detecting adenylylcyclase expression in a canine model of cardiomyopathy. In this model, in which cardiomyopathy was produced by rapid ventricular pacing, a loss of cardiac function was accompanied by a decrease in adenylylcyclase types V and VI mRNA levels. Our findings suggest therefore that a pretranslational mechanism may contribute, at least in part, to the loss in adenylylcyclase catalytic activity that has previously been reported in this model of heart failure.

\section{Methods}

Canine model of heart failure. Cardiac pacing was performed as previously described (6). Age-matched mongrel dogs of either sex were used. Dogs were anesthetized with halothane $(0.5-1.5 \mathrm{vol} / 100 \mathrm{ml}$ in 
$\mathrm{O}_{2}$ ) and ventilated on a Harvard respirator after induction with thiamylal sodium ( $10-15 \mathrm{mg} / \mathrm{kg}$ i.v.). A left thoracotomy was performed through the fifth intercostal space using sterile technique. Tygon catheters were placed in the descending thoracic aorta and left atrium. A solid state miniature pressure transducer was implanted in the apex of the left ventricle. Calibration was performed in vitro with a mercury manometer and in vivo using the left atrial and aortic catheter and strain gauge manometer (Statham Instruments, Oxnard, CA). Stainless steel pacing wires were placed on the right ventricle. 2 wk after the surgery, baseline hemodynamics were measured. Rapid ventricular pacing was initiated at a rate of 240 beats per min (bpm) 2 wk thereafter. The rate was controlled with an external programmable pacemaker (model EV 4543; Pace Medical Inc., Waltham, MA). Control animals were left without pacing after the surgery. Hemodynamics measurement were made with the dogs fully awake, lying quietly on their right side after a $>0.5$-h stabilization period subsequent to deactivation of pacing. Tissues were excised directly after the measurements and were used for biochemical assays. Animals used in this study were maintained in accordance with the guidelines of the Committee on Animals of the Harvard Medical school and the Guide for Care and Use of Laboratory Animals.

Membrane preparation and adenylylcyclase assay. Excised fat- and connective tissue-free left ventricle and septum were homogenized in a Polytron ( $5 \mathrm{~s}$, setting 6; Brinkmann Instruments, Westbury, NY) in buffer $(0.75 \mathrm{M} \mathrm{NaCl}$ and $10 \mathrm{mM}$ histidine, $\mathrm{pH} \mathrm{7.5})$. The homogenate was centrifuged at $14,000 \mathrm{~g}$ for $20 \mathrm{~min}$. The pellet was resuspended in the same buffer, and homogenization and centrifugation were repeated twice. The pellet was then resuspended in buffer $\left(10 \mathrm{mM} \mathrm{NaHCO}_{3}, 5\right.$ $\mathrm{mM}$ histidine, $\mathrm{pH} 8.0$ ), homogenized three times for $30 \mathrm{~s}$ in the Polytron, and centrifuged at $14,000 \mathrm{~g}$ for $20 \mathrm{~min}$. The pellet was resuspended in buffer containing $100 \mathrm{mM}$ TrisHCl ( $\mathrm{pH} 7.2$ ), 1 mM EGTA, and $5 \mathrm{mM} \mathrm{MgCl}{ }_{2}$ and homogenized in the Polytron, setting 6 . Finally the suspension buffer was filtered through one layer of silk screen and the pellet was centrifuged at $1,000 \mathrm{~g}$ for $15 \mathrm{~min}$ and stored at $-70^{\circ} \mathrm{C}$.

Adenylylcyclase activity was measured by the method of Salomon (20) using crude membranes prepared as above. Cardiac membranes were added to a solution containing $25 \mathrm{mM}$ TrisHCl, $20 \mathrm{mM}$ creatine phosphate, $1 \mathrm{U}$ creatine phosphokinase, $1 \mathrm{mM}$ ATP, $2-3 \times 10^{6} \mathrm{cpm}$ of $\left[{ }^{32} \mathrm{P}\right]$ ATP, $1 \mathrm{mM}$ cyclic AMP, 2,000-3,000 cpm of $\left[{ }^{3} \mathrm{H}\right]$ cyclic AMP as our internal standard, $5 \mathrm{mM} \mathrm{MgCl}_{2}, 1 \mathrm{mM}$ EDTA, and various stimulators. $10 \mu \mathrm{l}$ of stop solution ( $20 \%$ SDS) was added to each tube to terminate the reaction, and the tubes were heated in a dry bath at $100^{\circ} \mathrm{C}$ for 3 min. Radioactive cyclic AMP was isolated and analyzed as described. Protein concentration was measured by the method of Bradford (21) with bovine serum albumin used as a standard. Recovery from each column was $40-80 \%$.

Preparation of isolated heart cells. Canine cardiac myocytes were isolated by a method similar to that previously described $(22,23)$. Canine hearts were excised and placed in a cold modified Tyrode's solution containing the following (mM): $144 \mathrm{NaCl}, 24 \mathrm{NaHCO}_{3}, 4$ $\mathrm{KCl}, 1.6 \mathrm{NaH}_{2} \mathrm{PO}_{4}, 1.8 \mathrm{CaCl}_{2}, 1 \mathrm{MgCl}_{2}$, and 11 dextrose that had been equilibrated with $95 \% \mathrm{O}_{2} / 5 \% \mathrm{CO}_{2}$. In all subsequent steps all variations of Tyrode's solution were similarly equilibrated. A wedge of left ventricular myocardium with a prominent descending branch of the circumflex artery was removed. The artery was cannulated and transiently perfused with Tyrode's solution with $0.5 \mu \mathrm{l} / \mathrm{ml}$ green food coloring (Durkee, French Food Inc., Wayne, NJ), $10 \mathrm{mM}$ mannitol, and 1 $\mathrm{mg} / \mathrm{ml}$ bovine albumin added. Larger arterial leaks were ligated and the veins parallel to the main artery were punctured with a hypodermic needle; the tissue was then perfused for $4.5 \mathrm{~min}$ with a $37^{\circ} \mathrm{C}$ calciumand magnesium-free Tyrode's solution that was supplemented with 20 $\mathrm{mM}$ taurine, $10 \mathrm{mM}$ mannitol, $5 \mathrm{mM}$ pyruvic acid and $1 \mathrm{~mm} / \mathrm{ml}$ bovine albumin. This was followed by a 12 -min perfusion with $100 \mu \mathrm{M}$ calcium-containing Tyrode's solution containing $0.9 \mathrm{mg} / \mathrm{ml}$ collagenase A (Boehringer Mannheim Corp., Indianapolis, IN), $20 \mathrm{mM}$ taurine, $10 \mathrm{mM}$ mannitol, $5 \mathrm{mM}$ pyruvic acid, and $1 \mathrm{mg} / \mathrm{ml}$ bovine albu$\min$. The tissue was removed from the cannula, epicardial and endocardial surfaces were removed, and the tissue was minced into
2-3- $\mathrm{mm}^{3}$ pieces. The minced tissues were then incubated for 15-min cycles in $37^{\circ} \mathrm{C}$ collagenase solution. During these cycles tissue chunks were gently agitated by bubbling with $\mathrm{O}_{2} / \mathrm{CO}_{2}$. At the end of each cycle, the supernatant was poured through a $200-\mu \mathrm{m}$ nylon mesh and fresh enzyme solution was added to the tissue. The cells in the supernatant were pelleted at $50 \mathrm{~g}$ and placed in a resuspension solution containing the following (mM) $133 \mathrm{NaCl}, 4.7 \mathrm{KCl}, 20$ Hepes ( $\mathrm{pH} 7.4$ ), 1.2 $\mathrm{MgSO} 4,0.1 \mathrm{CaCl} 2,11$ dextrose, 10 mannitol, 5 pyruvic acid and 1 $\mathrm{mg} / \mathrm{ml}$ bovine albumin and $20 \mu \mathrm{g} / \mathrm{ml}$ gentamycin. Percoll enrichment was used to increase the percentage of myocytes in the cell pellet. Cells were placed in the resuspension solution containing 45\% Percoll and centrifuged at $400 \mathrm{rpm}$ for $5 \mathrm{~min}$. The resulting cell pellet was washed in the resuspension solution to remove Percoll. The total number of cells was counted microscopically, which includes cardiac myocytes, blood cells, smooth muscle cells, fibroblasts, or endothelial cells and the percentage of cardiac myocytes was thereby determined.
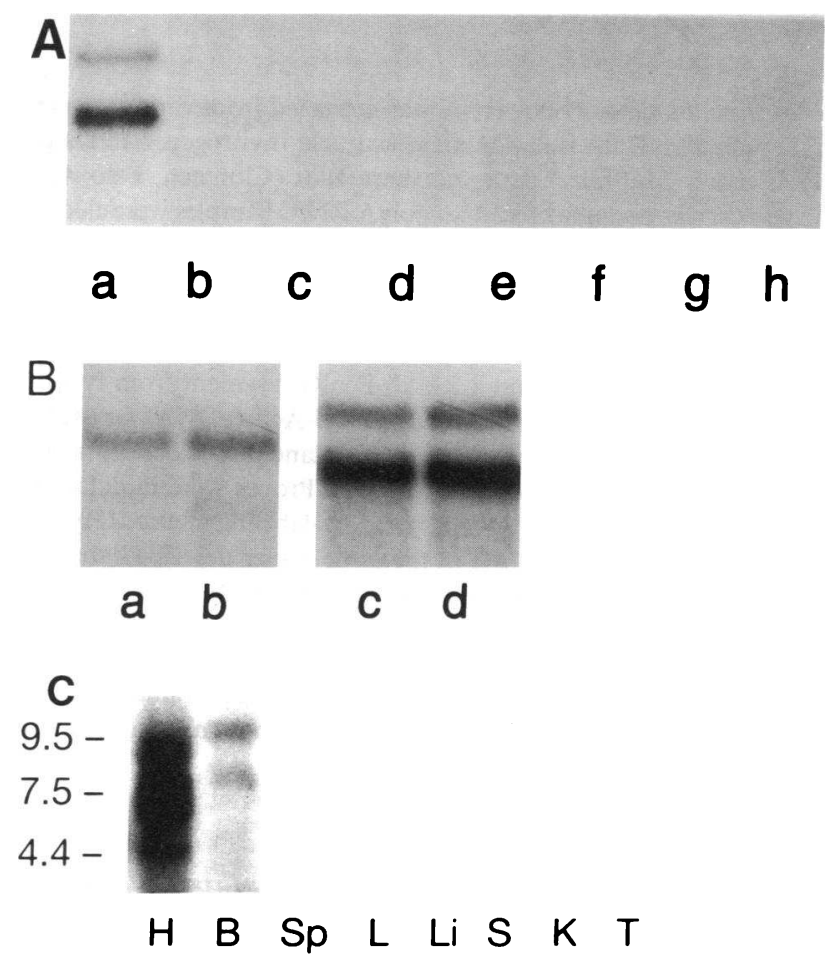

Figure 1. Tissue distribution of type V adenylylcyclase mRNA. (A) 5 $\mu \mathrm{g}$ of polyA RNA from various tissues and cell lines were used. $(B)$ $2 \mu \mathrm{g}$ of polyA RNA from the whole myocardium and purified cardiocytes were used. $(C)$ Human multiple Northern blot (Clontech, Palo Alto, CA) was used. The blots were prehybridized in a solution with $50 \%$ formamide, $5 \times$ SSC, $5 \times$ Denhardt's $25 \mathrm{mM} \mathrm{NaPO}_{4}(\mathrm{pH}$ $6.5), 0.25 \mathrm{mg} / \mathrm{ml}$ calf thymus DNA, and $0.1 \%$ SDS at $42^{\circ} \mathrm{C}$ for $2 \mathrm{~h}$ before addition of the probe. Hybridization was performed at $42^{\circ} \mathrm{C}$ for $18 \mathrm{~h}$ followed by washing under increasingly stringent conditions. An EcoRI-HincII 1.5-kb fragment from type $\mathrm{V}$ adenylylcyclase cDNA was used as a probe. The probe was made by the multiprimer random priming method with $\left[{ }^{32} \mathrm{P}\right] \mathrm{dCTP} .(A) a$, canine brain; $b$, canine skeletal muscle; $c$, canine kidney; $d$, canine testis; $e$, canine lung; $f$, NIH 3T3 mouse fibroblast; $g$, S49 mouse lymphoma cells; $h$, bovine aortic endothelial cells. $(B) a$ and $c$, canine whole myocardium; $b$ and $d$, purified canine cardiocytes. On average the percentage of cardiocytes ( $b$ and $d$ ), either rod- or round-shaped cells, was $92 \%$ (ranged between $85 \%$ and $100 \%$ ), which was increased from $62 \%$ (ranged between $48 \%$ and $82 \%$ ) before the purification. An EcoRI 5.6-kb fragment from type VI adenylylcyclase cDNA was used as a probe in lanes $a$ and $b$. $(C) \mathrm{H}$, heart; $\mathrm{B}$, brain; Sp, spleen; $\mathrm{L}$, lung; $\mathrm{Li}$, liver; S, skeletal muscle; K, kidney; T, testis. 
Table I. Baseline Hemodynamic Parameters in Control and Heart Failure Dogs

\begin{tabular}{lcccccc}
\hline & LVEDP* & LVdP/dt* & MAP* & $\mathrm{LVP}^{*}$ & $\mathrm{HR}^{*}$ & $n$ \\
\hline & $m m H g$ & $m m H g / s$ & $m m H g$ & $m m H g$ & $b p m$ & \\
$\begin{array}{c}\text { Control } \\
\text { (sham }\end{array}$ & & & & & & \\
operated) & $5.4 \pm 0.2$ & $2950 \pm 84$ & $93 \pm 2.0$ & $118 \pm 4.0$ & $85 \pm 4$ & 6 \\
Heart failure & $5.7 \pm 0.7$ & $2952 \pm 138$ & $96 \pm 3.0$ & $121 \pm 3.0$ & $89 \pm 4$ & 6
\end{tabular}

All measurements were obtained $\sim 2 \mathrm{wk}$ after recovery from surgical instrumentation and before the initiation of pacing. LVEDP, left ventricular end-diastolic pressure; LVdP/dt, isovolumic index; MAP, mean arterial pressure; LVP, left ventricular pressure; and HR, heart rate. $n=$ number of dogs examined. ${ }^{*} P=$ NS between the two groups, means \pm SEM are shown.

Northern blotting. PolyA RNA was extracted from various canine tissues with an mRNA isolation kit (Fasttrack; Invitrogen, San Diego, CA). Human Multiple Tissue Northern Blot (Clontech, Palo Alto, CA) was used as a source of human polyA RNA. Samples were electrophoresed in a formaldehyde-agarose gel. After transfer, blots were prehybridized in a solution containing $50 \%$ formamide, $5 \times$ SSC, $5 \times$ Denhardt's, $25 \mathrm{mM} \mathrm{NaPO}_{4}$ ( $\mathrm{pH} 6.5$ ), $0.25 \mathrm{mg} / \mathrm{ml}$ calf thymus DNA, and $0.1 \%$ SDS at $42^{\circ} \mathrm{C}$ for $2 \mathrm{~h}$. A 1.5 -kb EcoRI-Hincll fragment from type $\mathrm{V}$ adenylylcyclase cDNA and a 5.6-kb EcoRI fragment from type VI adenylylcyclase cDNA were used as probes. $\beta$-Actin cDNA was used as a probe for quantitating the loading in each lane. Probe concentration was far in excess of those of the messages. Probes were radiolabeled with [ $\left.{ }^{32} \mathrm{P}\right] \mathrm{dCTP}$ by the multiprimer random-labeling method. Hybridization was allowed to proceed in the same buffer described above at $42^{\circ} \mathrm{C}$ for $18 \mathrm{~h}$ followed by washing under increasingly stringent conditions. mRNA expression was measured by densitometry (GS300; Hoefer Scientific Instruments, San Francisco, CA) or by direct counting using a Betascope (Betagen, Waltham, MA). Each value represents the relative ratio of the amount of adenylylcyclase mRNA to that of $\beta$-actin mRNA.

\section{Results}

Expression of adenylylcyclase type V and VI mRNAs in human and canine tissues. For type $\mathrm{V}$, the distribution was limited to the heart and brain in both species (Fig. $1 A$ ). As previously described (16), noncardiocytes, such as the NIH 3T3 fibroblast, aortic endothelial cells, and S49 lymphoma cells, did not express type $\mathrm{V}$ mRNA. When purified cardiocytes were used as a source of polyA RNA, detection of the types V and VI messages was similar or even enhanced in comparison to that ob- tained when polyA RNA was prepared from the intact myocardium (Fig. $1 B$ ). Cardiocytes were counted before and after the purification as described in Methods and were pooled to extract polyA RNA. On average, the percentage of cardiocytes (Fig. $1 B, b$ and $d$ ), either rod- or round-shaped cells, was $92 \%$ (ranged between $85 \%$ and $100 \%$ ), which was increased from $62 \%$ (ranged between $48 \%$ and $82 \%$ ) before the purification. The percentage of rod-shaped cells ranged between $53 \%$ and $90 \%$ in the final preparation. In canine tissues, two species of type $V$ mRNA were expressed ( 5 and $7 \mathrm{~kb}$ in size) in both heart and brain as we reported previously (16), whereas, in the human, the size distribution between heart and brain was different. Heart contained multiple species of mRNA ranging from $\sim 4.4$ to $9.5 \mathrm{~kb}$ in size whereas brain contained only two messages of $\sim 8.0$ and $9.5 \mathrm{~kb}$ in size (Fig. $1 C$ ). We have also isolated fragments of type $\mathrm{V}$ adenylylcyclase cDNA $(\sim 2.5 \mathrm{~kb})$ from a human cardiac cDNA library, which showed a high sequence homology to the canine type $\mathbf{V}$ adenylylcyclase cDNA (> 90\%) (Y. Ishikawa, unpublished observation). For type VI, only one mRNA species was detected in all the tissues examined in both species as previously described (data not shown; reference 17).

Creation of congestive heart failure in dogs by rapid ventricular pacing. Tables I and II compare the physiological parameters of control and heart failure animals before and after pacing. There was no significant difference in baseline hemodynamics between the two groups before pacing (Table I). After pacing, there was a significant increase in left ventricular contractile dysfunction in paced animals. Heart rate and left ventricular end-diastolic pressure increased significantly. In contrast, the left ventricular isovolumic index decreased significantly. Signs of heart failure, i.e., exercise intolerance, ascites, edema, were all observed in the paced animals. There was no difference in the ratio of left ventricular and septal weight to body weight between the two groups, indicating that pacing did not induce cardiac hypertrophy. Pacing had no effect on the total number of $\beta$-adrenergic receptors; however, there was a significant reduction in the number of high affinity binding sites as determined by radioligand binding assay $(44 \pm 1$ to $30 \pm 2 \mathrm{fmol} / \mathrm{mg} \cdot$ protein ). No change in the activity of Gs protein was detected, as determined by a reconstitution assay with $\mathrm{S} 49 \mathrm{cyc}^{-}$cells (24). Some of the hemodynamic data, as well as those for cyclase activity, Gs, and $\beta$-adrenergic receptor, are included in a previous report (6).

Reduction in cardiac adenylylcyclase mRNA levels and loss of catalytic activity. Fig. 2 shows a comparison between the loss of adenylylcyclase activity and a decrease in the steady state

Table II. Hemodynamic Parameters after Pacing in Control and Heart Failure Dogs

\begin{tabular}{|c|c|c|c|c|c|c|c|}
\hline & LVEDP & $\mathrm{LVdP} / \mathrm{dt}$ & MAP & LVP & HR & B/H & $n$ \\
\hline & $m m H g$ & $\mathrm{mmHg} / \mathrm{s}$ & $m m H g$ & $m m H g$ & $b p m$ & & \\
\hline Control & $5.3 \pm 0.2$ & $2971 \pm 92$ & $95 \pm 2$ & $120 \pm 2$ & $84 \pm 4$ & $5.2 \pm 0.1$ & 6 \\
\hline \multicolumn{8}{|l|}{ Heart } \\
\hline failure & $26 \pm 3.2^{*}$ & $1412 \pm 53^{*}$ & $79 \pm 3^{*}$ & $96 \pm 4^{*}$ & $131 \pm 7^{*}$ & $5.0 \pm 0.2$ & 6 \\
\hline
\end{tabular}

Ventricular pacing $(240 \mathrm{bpm})$ was initiated and continued for $4 \mathrm{wk}$ in chronically instrumented, conscious dogs as described. Control dogs were left without pacing. LVEDP, left ventricular end-diastolic pressure; LVdP/dt, isovolumic index; MAP, mean arterial pressure; LVP, left ventricular pressure; $\mathrm{HR}$, heart rate; and $\mathrm{B} / \mathrm{H}$, ratio between body weight and left ventricular and septal weight. $n=$ number of dogs examined. ${ }^{*} P<0.005$ difference from the control, means \pm SEM are shown. 

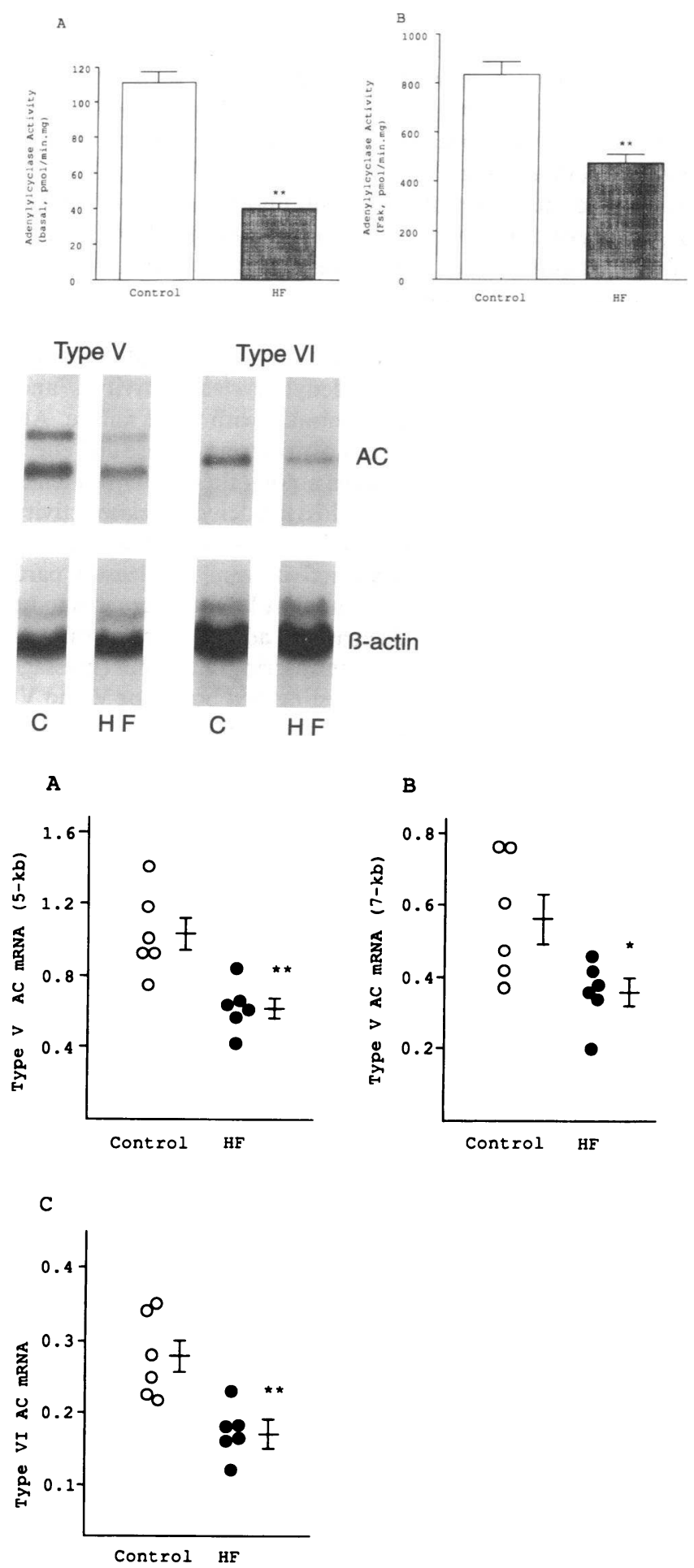

Figure 2. Reduction in cardiac adenylylcyclase mRNA levels and loss of catalytic activity. ( Top) Reduction in cardiac adenylylcyclase catalytic activity. Crude membrane preparation from control (Control) and heart failure dogs $(H F)$ and adenylylcyclase assay were performed as described in Methods. $(A)$ Basal adenylylcyclase activity (pmol/ $\mathrm{min}^{-1} \cdot \mathrm{mg}^{-1} \cdot$ protein $\left.^{-1}\right)$ : control, $111 \pm 6.3$ and $\mathrm{HF}{ }^{* *} 40 \pm 2.7,(B)$ forskolin $(100 \mu \mathrm{M})$-stimulated adenylylcyclase activity (pmol/ $\min ^{-1} \cdot \mathrm{mg}^{-1} \cdot$ protein $\left.{ }^{-1}\right)$ : control, $836 \pm 54$ and HF, ${ }^{* *} 475 \pm 33 .{ }^{* *} P$ $<0.005 ; n=6$ for each group; means \pm SEM are shown. (Middle and Bottom) Reduction in type V and VI mRNA steady state levels. $5 \mu \mathrm{g}$ of polyA RNA obtained from left ventricular tissue was used. $\beta$-actin cDNA was used as a probe for quantitating the loading in each lane. adenylylcyclase mRNA levels from control and heart failure animals. After 4 wk of overdrive pacing, both basal and forskolin-stimulated myocardial adenylylcyclase catalytic activity decreased significantly (basal activity $\left[\mathrm{pmol} / \mathrm{min}^{-1} \cdot \mathrm{mg}^{-1}\right.$. protein $^{-1}$ ], control, $111 \pm 6.3$ and heart failure, $* * 40 \pm 2.7$; forskolin $(100 \mu \mathrm{M})$-stimulated activity $\left[\mathrm{pmol} / \mathrm{min}^{-1}\right.$. $\mathrm{mg}^{-1} \cdot$ protein $\left.^{-1}\right]$, control, $836 \pm 54$ and heart failure, $* * 475 \pm 33$, $n=6$ for each group, means \pm SEM, ${ }^{* *} P<0.005$ difference from control). Similarly, expression of both types of adenylylcyclase mRNA decreased significantly. It is interesting to note that the content of both type $\mathrm{V}$ mRNA species (a major band of $5 \mathrm{~kb}$ and a minor band of $7 \mathrm{~kb}$ ), which are possibly splicing variants (Y. Ishikawa et al., unpublished observation), decreased to a similar degree (type V, 5-kb message: control, $1.04 \pm 0.09$ and heart failure, ${ }^{* *} 0.62 \pm 0.05 ; 7-\mathrm{kb}$ message: control, $0.56 \pm 0.07$ and heart failure, ${ }^{*} 0.36 \pm 0.03$; type VI message: control $0.27 \pm 0.02$ and heart failure, ${ }^{* *} 0.17 \pm 0.01$. $^{* *} P$ $<0.005,{ }^{*} P<0.05$ difference from control, $n=6$ for each group, means \pm SEM).

The amount of adenylylcyclase mRNA expression was standardized using $\beta$-actin mRNA as a control. We also examined whether a change in the content of $\beta$-actin mRNA expression occurred in heart failure animals. The amount of $\beta$-actin mRNA expression in heart failure has been reported to be decreased $(25,26)$ or unchanged $(27)$. We compared the amount of $\beta$-actin mRNA expression to that of $28 \mathrm{~S}$ ribosomal RNA expression using total RNA obtained from the control and HF groups. The relative ratio between the two did not show any significant difference (control, $2.92 \pm 0.52$ and heart failure, $2.57 \pm 0.26, P=\mathrm{NS}, n=5$ for each group). Thus using $\beta$-actin mRNA content as a control for quantitating changes in the content of adenylylcyclase mRNA appears valid.

\section{Discussion}

The present study demonstrates that a decrease in the content of types $\mathrm{V}$ and VI adenylylcyclase mRNA accompanies the loss in adenylylcyclase catalytic activity in an animal model of pacing-induced cardiomyopathy. We have also confirmed that types V and VI adenylylcyclase isoforms are expressed in human heart, suggesting that changes in the expression of these isoforms may potentially contribute to altered catalytic activity in human cardiomyopathy. Distribution of type $\mathrm{V}$ mRNA expression is similar between human and dog; it is most abundant in the heart, with a lesser amount in the brain, but is absent in a variety of other tissues, including kidney (16). A recent study has shown that type $\mathrm{V}$ mRNA is present also in the kidney in the rat, suggesting that distribution of type $\mathrm{V}$ mRNA expression occurs in a species-specific manner (28).

The amounts of adenylylcyclase mRNA expression were standardized with the amount of $\beta$-actin expression. (Middle) Examples of Northern blots obtained both in normal and heart failure animals are shown. (Lower) The actual data derived from each animal are shown. $(A)$ expression of type $\mathrm{V}$ adenylylcyclase mRNA, 5-kb message: control, $1.04 \pm 0.09$ and HF, ${ }^{* *} 0.62 \pm 0.05 ;(B)$ expression of type $\mathrm{V}$ adenylylcyclase mRNA, 7-kb message: control, $0.56 \pm 0.07$ and $\mathrm{HF}$ ${ }^{*} 0.36 \pm 0.03 ;(C)$ expression of type VI adenylylcyclase mRNA: control $0.27 \pm 0.02$ and $\mathrm{HF},{ }^{* *} 0.17 \pm 0.01 .{ }^{* *} P<0.005,{ }^{*} P<0.05 ; n=6$; means \pm SEM are shown. 
Reported adenylylcyclase catalytic activities in heart failure have been variable, with some studies demonstrating a decrease in basal activity $(5,29)$ and others demonstrating a normal basal and stimulated adenylylcyclase activity (30). Direct evaluation of catalytic unit activity has been difficult; crude membranes can be variably contaminated with GTP and this could differ among the particular membrane preparations used. Investigators have hypothesized that both basal and stimulated adenylylcyclase activities mirror the activity of catalyst itself. Basal activity may be altered in the presence of variable amounts of GTP or G proteins. Similarly, forskolin-stimulated catalytic activity needs $G_{s}$ for its maximal stimulation. $\mathrm{Mn}^{2+}$ has been used as a selective probe for adenylylcyclase catalytic unit activity ( 31 ) because, unlike forskolin, $\mathrm{Mn}^{2+}$ activation of catalytic unit is not affected by the presence of $\mathrm{G}$ protein. However, $\mathrm{Mn}^{2+}$-activated catalytic activity could be altered either by adenosine or its analogs working at the allosteric $P$ site or if complete uncoupling from $G_{s}$ has not been affected (32). Other common cellular components, such as calcium, calmodulin, or even $\beta \gamma$ subunits of $G$ proteins, can be latent modulators of catalytic activity in crude membrane preparations (3234). Most importantly, membrane catalytic activity is the sum of catalytic activity of different adenylylcyclase isoforms coexisting even within a single cell type. With the recent cloning of various members of this family, probes, both antibody and cDNA, will allow investigators to examine the role of specific isoforms in contributing to an impairment or enhancement of a particular signal transduction pathway. The importance of this issue is that these isoforms show a different sensitivity to various stimulants, including $\beta \gamma$ subunits (34). Thus the impact of activating multiple cell surface receptors, both stimulatory and inhibitory, on the accumulation of intracellular cyclic AMP will be different based on the characteristics of the particular adenylylcyclase isoforms that are being expressed.

Recent cloning of cDNAs of cardiac adenylylcyclase isoforms $(16,17)$ has permitted the direct assessment of their mRNA expression. A recent study has shown that heart expresses another form of adenylylcyclase; type IV is widely expressed in variable tissues, including the heart at a low level (15). Type $\mathrm{V}$ is unique in its tissue distribution, which is expressed abundantly only in the brain and heart; while it is not expressed in other tissues, including fibroblasts or lymphocytes (16). In purified cardiocytes the type V mRNA was even more apparent as compared with the entire myocardium that includes fibroblasts, smooth muscle, and endothelial cells. Taken together, these data suggest that decrease in the content of type $\mathrm{V}$ mRNA in the heart of animals with failure principally reflects a decrease in the content of type V mRNA in cardiocytes.

Decreases in adenylylcyclase type $\mathrm{V}$ and type VI mRNA levels correlated with the decline in adenylylcyclase catalytic activity as well. These results suggest that a decrease in adenylylcyclase catalytic activity resulted, at least in part, from a reduction in the steady state mRNA levels of types $\mathrm{V}$ and VI adenylylcyclase. If the message levels were not different, then either posttranslational modification of the enzyme, enhanced turnover of the protein, or even the invalidity of this assay system could be implicated. Posttranslational modification of adenylylcyclase via phosphorylation has been shown in frog erythrocytes in response to phorbol ester treatment (35). Several other studies have indicated that modification of catalytic activity, either an increase or decrease, can occur after activation of protein kinase $\mathrm{C}$, possibly related to the isoform of the adenylylcyclase and kinase in that particular tissue (36-38). Our data, i.e., reduced steady state mRNA levels, suggest that transcriptional or posttranscriptional events, e.g., mRNA stability, contribute to the decreased adenylylcyclase activity of heart failure although we can not exclude the existence of such post-translational regulatory mechanisms. Direct quantification of the enzyme protein by immunoblotting has thus far been hampered by its very low quantity in the membrane preparations, despite the fact that we have used relatively high titer antipeptide antisera in an attempt to measure the protein by Western blotting.

Reductions in physiological function (contractile parameters), biochemical activity (adenylylcyclase activity), and mRNA levels all occurred in animals with heart failure. Although these data do not necessarily indicate a cause and effect relationship, the parallel changes among these activities lends credence to the suggestion that a loss in adenylylcyclase activity plays a role in the progression of ventricular dysfunction and that this loss in adenylylcyclase activity results, at least in part, from a decrease in steady state mRNA levels. It remains to be determined whether the decrease in adenylylcyclase mRNA levels is a transcriptional or posttranscriptional event (message stability). It is particularly interesting that both type V and VI mRNA levels were decreased. It may be possible to begin examining this issue by using in vitro techniques to define the factors that regulate adenylylcyclase mRNA levels in isolated cardiocytes. Ultimately, in vivo approaches using transgenic animals to examine the factors regulating transcription from the adenylylcyclase gene in states of heart failure will be required to define the underlying mechanism.

\section{Acknowledgments}

This work was supported in part by U.S. Public Service grants HL38070, HL-37404, HL-33065, and HL-45332 and by a grant from American Cyanamid Company-Lederle Laboratories.

\section{References}

1. Homcy, C. J., S. F. Vatner, and D. E. Vatner. 1991. Beta-adrenergic receptor regulation in the heart in pathophysiological states: abnormal adrenergic responsiveness in cardiac disease. Annu. Rev. Physiol. 53:137-159.

2. Feldman, M. D., L. Copelas, J. K. Gwathmey, P. Phillips, S. E. Warren, F. Schoen, W. Grossman, and J. P. Morgan. 1987. Deficient production of cyclic AMP: pharmacological evidence of an important cause of contractile dysfunction in patients with end-stage heart failure. Circulation. 75:331-339.

3. Bristow, M. R., F. L. Anderson, J. D. Port, L. Skerl, R. E. Hershberger, P. Larrabee, J. B. O'Connell, D. G. Renlund, K. Volkman, J. Murray, et al. 1991. Differences in beta-adrenergic neuroeffector mechanisms in ischemic versus idiopathic dilated cardiomyopathy. Circulation. 84:1024-1039.

4. Longabaugh, J. P., D. E. Vatner, S. F. Vatner, and C. J. Homcy. 1988. Decreased stimulatory guanosine triphosphate binding protein in dogs with pressure-overload left ventricular failure. J. Clin. Invest. 81:420-424.

5. Chen, L., D. E. Vatner, S. F. Vatner, L. Hittinger, and C. J. Homcy. 1991. Decreased $\mathrm{G}_{\mathrm{s} \alpha} \mathrm{mRNA}$ levels accompany the fall in $\mathrm{G}_{\mathbf{s}}$ and adenylyl cyclase activities in compensated left ventricular hypertrophy. J. Clin. Invest. 87:293-298.

6. Kiuchi, K., R. P. Shannon, K. Komamura, D. J. Cohen, C. Bianchi, C. J. Homcy, S. F. Vatner, and D. E. Vatner. 1993. Myocardial beta-adrenergic receptor function during the development of pacing-induced heart failure. J. Clin. Invest. 91:907-914.

7. Marzo, K. P., M. J. Frey, J. R. Wilson, B. T. Liang, D. R. Manning, V. Lanoce, and P. B. Molinoff. 1991. Beta-adrenergic receptor-G protein-adenylate cyclase complex in experimental canine congestive heart failure produced by rapid ventricular pacing. Circ. Res. 69:1546-1556.

8. Calderone, A., M. Bouvier, K. Li, C. Juneau, J. Champlain, and J. Rouleau. 1991. Dysfunction of the $\beta$ - and $\alpha$-adrenergic systems in a model of congestive heart failure: the pacing-overdrive dog. Circ. Res. 69:332-343.

9. Cruz, F. E. S., E. Cheriex, J. Dmeets, J. Atie, A. Peres, O. Penn, P. Brugada, and H. Wellens. 1990. Reversibility of tachycardia-induced cardiomyopathy 
after cure of incessant supraventricular tachycardia. J. Am. Coll. Cardiol. 16:739-744.

10. Gillete, P. C., R. Smith, J. A. Garson, C. Mullins, H. Gutgesell, C. D. Goh, and D. G. McNamara. 1985. Chronic supraventricular tachycardia. JAMA (J. Am. Med. Assoc.). 253:391-392.

11. Lemery, R., P. Brugada, E. Cheriex, and H. J. J. Wellens. 1987. Reversibility of tachycardia-induced left ventricular dysfunction after closed-chest catheter ablation of the atrioventricular junction for intractable atrial fibrillation. Am. J. Cardiol. 60:1406-1408.

12. Krupinski, J., F. Coussen, H. A. Bakalyar, W. J. Tang, P. G. Feinstein, K. Orth, C. Slaughter, R. R. Reed, and A. G. Gilman. 1989. Adenylyl cyclase amino acid sequence: possible channel- or transporter-like structure. Science (Wash. DC). 244:1558-1564.

13. Feinstein, P. G., K. A. Schrader, H. A. Bakalyar, W.-J. Tang, J. Krupinski, A. G. Gilman, and R. R. Reed. 1991. Molecular cloning and characterization of a $\mathrm{Ca} /$ calmodulin-sensitive adenylyl cyclase from rat brain. Proc. Natl. Acad. Sci. USA. 88:10173-10177.

14. Bakalyar, H., and R. R. Reed. 1990. Identification of a specialized adenylyl cyclase that may mediate odorant detection. Science (Wash. DC). 250:1403-1406.

15. Gao, B., and A. G. Gilman. 1991. Cloning and expression of a widely distributed (type IV) adenylyl cyclase. Proc. Natl. Acad. Sci. USA. 88:1017810182.

16. Ishikawa, Y., S. Katsushika, L. Chen, N. J. Halnon, J. Kawabe, and C. J. Homcy. 1992. Isolation and characterization of a novel cardiac adenylyl cyclase cDNA. J. Biol. Chem. 267:13553-13557.

17. Katsushika, S., L. Chen, J. Kawabe, R. Nilakantan, N. J. Halnon, C. J. Homcy, and Y. Ishikawa. 1992. Cloning and characterization of a sixth adenylyl cyclase isoform: types V and VI constitute a subgroup within the mammalian adenylyl cyclase family. Proc. Natl. Acad. Sci. USA. 89:8774-8778.

18. Gros, P., J. Croop, and D. Housman. 1986. Mammalian multi-drug resistance gene: complete cDNA sequence indicates strong homology to bacterial transport proteins. Cell. 47:371-380.

19. Rommens, J. M., M. C. Iannuzzi, B. Karen, M. L. Drumm, G. Melmer, M. Dean, R. Rozmahel, J. L. Cole, D. Kennedy, N. Hidaka, et al. 1989. Identification of the cystic fibrosis gene: chromosome walking and jumping. Science (Wash. DC). 245:1059-1065.

20. Salomon, Y. 1979. Adenylate cyclase assay. Adv. Cyclic Nucleotide Res. 10:35-55.

21. Bradford, M. 1976. A rapid and sensitive method for the quantitation of microgram quantities of protein utilizing the principle of protein-dye binding. Anal. Biochem. 72:248-254.

22. Gupta, R. K., and B. A. Wittenberg. 1991. P-NMR studies of isolated adult heart cells: effect of myoglobin inactivation. Am. J. Physiol. 262:H1155H1163.

23. Hewett, K., M. J. Legato, P. Danilo, and R. B. Robinson. 1983. Isolated myocytes from adult canine left ventricle: $\mathrm{Ca}$ tolerance, electrophysiology and ultrastructure. Am. J. Physiol. 245:H830-H839.
24. Susanni, E. E., W. T. Manders, D. R. Knight, D. E. Vatner, S. F. Vatner, and C. J. Homcy. 1989. One hour of myocardial ischemia decreases the activity of the stimulatory guanine-nucleotide regulatory protein $\mathrm{G}_{\mathbf{s}}$. Circ. Res. 65:11451150.

25. Feldman, A. M., P. E. Ray, and M. R. Bristow. 1991. Expression of alpha-subunit of $\mathbf{G}$ protein in failing human heart: a reappraisal utilizing quantitative polymerase chain reaction. J. Mol. Cell. Cardiol. 23:1355-1358.

26. Feldman, A. M., P. E. Ray, C. M. Silan, J. A. Mercer, W. Minobe, and M. R. Bristow. 1991. Selective gene expression in failing human heart. Quantification of steady-state levels of mRNA in endomyocardial biopsies using the polymerase chain reaction. Circulation. 83:1866-1872.

27. Ungerer, M., M. Bohm, J. S. Elce, E. Erdmann, and M. J. Lohse. 1993. Altered expression of beta-adrenergic receptor kinase and beta-adrenergic receptors in the failing human heart. Circulation. 87:454-463.

28. Premont, R. T., J. Chen, H. W. Ma, M. Ponnapalli, R. Iyengar. 1992. Two members of a widely expressed subfamily of hormone-stimulated adenylyl cyclases. Proc. Natl. Acad. Sci. USA. 89:9809-9813.

29. Vatner, D. E., S. F. Vatner, A. U. Fujii, and C. J. Homcy. 1985. Loss of high affinity cardiac beta adrenergic receptors in dogs with heart failure. J. Clin. Invest. 76:2259-2264.

30. Bristow, M., R. Ginsberg, A. Strosberg, W. Montgomery, and W. Minobe. 1984. Pharmacology and inotropic potential of forskolin in the human heart. $J$. Clin. Invest. 74:212-223.

31. Strittmatter, S., and E. J. Neer. 1980. Properties of the separated catalytic and regulatory units of brain adenylate cyclase. Proc. Natl. Acad. Sci. USA. 77:6344-6348.

32. Tang, W. J., J. Krupinski, and A. G. Gilman. 1991. Expression and characterization of calmodulin-activated (type I) adenylylcyclase. J. Biol. Chem. 266:8595-8603.

33. Tang, W. J., and A. G. Gilman. 1992. Type-specific regulation of adenylyl cyclase by $G$ protein beta/gamma subunits. Science (Wash. DC). 254:15001503.

34. Federman, A. D., B. R. Conklin, K. A. Schrader, R. R. Reed, and H. R. Bourne. 1992. Hormonal stimulation of adenylyl cyclase through $G$ protein beta/ gamma subunits. Science (Wash. DC). 356:159-161.

35. Yoshimasa, T., D. R. Sibley, M. Bouvier, R. J. Lef kowitz, and M. G. Caron. 1987. Cross-talk between cellular signaling pathways suggested by phorbol ester-induced adenylate cyclase phosphorylation. Nature (Lond.). 327:67-70.

36. Bell, J. D., I. L. O. Buxton, and L. L. Brunton. 1985. Enhancement of adenylate cyclase activity in $\mathbf{S 4 9}$ lymphoma cells by phorbol esters. J. Biol. Chem. 260:2625-2628.

37. Rebois, R. V., and J. Patel. 1985. Phorbol ester causes desensitization of gonadotropin-responsive adenylate cyclase in a murine Leydig tumor cell line. $J$. Biol. Chem. 260:8026-8031.

38. Heyworth, C. M., A. D. Whetton, A. R. Kinsella, and M. D. Houslay. 1984. The phorborester. TPA inhibits glucagon-stimulated adenylate cyclase activity. FEBS (Fed. Eur. Biochem. Soc.) Lett. 170:38-42. 